\title{
An Asn > Lys substitution in saposin B involving a conserved amino acidic residue and leading to the loss of the single $\mathrm{N}$-glycosylation site in a patient with metachromatic leukodystrophy and normal arylsulphatase A activity
}

\author{
Stefano R egis ${ }^{1}$, Mirella Filocamo ${ }^{1}$, Fabio Corsolini ${ }^{1}$, Francesco Caroli ${ }^{2}$, \\ Joke LM Keulemans ${ }^{3}, O$ tto $P$ van Diggelen ${ }^{3}$ and R osanna $G$ atti $^{1}$ \\ ${ }^{1} \mathrm{~L}$ aboratorio di Diagnosi Pre e Postnatale di M alattie M etaboliche, Istituto $G$ G aslini \\ ${ }^{2} \mathrm{~L}$ aboratorio di G enetica Molecolare, Istituto G G aslini, G enoa, I taly \\ ${ }^{3} \mathrm{D}$ epartment of C linical $\mathrm{G}$ enetics, E rasmus U niversity, R otterdam, The N etherlands
}

\begin{abstract}
Sphingolipid activator proteins are small glycoproteins required for the degradation of sphingolipids by specific lysosomal hydrolases. Four of them, called saposins, are encoded by the prosaposin gene, the product of which is proteolytically cleaved into the four mature saposin proteins (saposins A , B, C, D ). O ne of these, saposin B, is necessary in the hydrolysis of sulphatide by arylsulphatase $A$ where it presents the solubilised substrate to the enzyme. A $s$ an alternative to arylsulphatase A deficiency, deficiency of saposin B causes metachromatic leukodystrophy. We identified a previously undescribed mutation (N215K) in the prosaposin gene of a patient with metachromatic leukodystrophy but with normal arylsulphatase A activity and elevated sulphatide in urine. The mutation involves a highly conserved amino acidic residue and abolishes the only $\mathrm{N}$-glycosylation site of saposin $\mathrm{B}$.
\end{abstract}

Keywords: sphingolipid activator proteins; cerebroside sulphate activator; metachromatic leukodystrophy

\section{Introduction}

The lysosomal degradation of sphingolipids is operated by specific hydrolases, some of which require the presence of small non-enzymic glycoproteins called sphingolipid activator proteins. ${ }^{1} \mathrm{~A}$ mong them, the four

Correspondence: Professor Rosanna Gatti, Laboratorio di D iagnosi Pre e Postnatale di M alattie M etaboliche, I stituto $G$ G aslini, Largo G G aslini 5, 16147 G enova, I taly. Tel: 003910 5636350; Fax: 003910 3776590; E-mail: bang@mbox.ulisse.it R eceived 8 June 1998; revised 25 A ugust 1998; accepted 21 September 1998 saposins have a common precursor. The prosaposin gene $(P S A P)^{2-4}$ (cD NA sequence in GenBank, accession number D00422; genomic DNA sequence in $\mathrm{G}$ enB ank, accession number $M$ 86181), encodes a polypeptide, glycosylated at five sites, which is transported to lysosomes where it is processed to produce the four mature saposins. ${ }^{1}$ The physiological role of saposin $A$ ( sap-A) and saposin-D (sap-D) has not been completely elucidated. In vitro experiments suggest that sap-A stimulates glucosylceramidase and galactosylceramidase. ${ }^{1}$ Sap-D seems to activate the hydrolysis of ceramide. ${ }^{5,6}$ Saposin C (sap-C) and saposin B (sap-B) 
have been more extensively characterised. Sap-C is essential for the degradation of glucosylceramide and galactosylceramide; deficiency of sap-C results in a variant form of $G$ aucher disease. Sap-B solubilises the glycolipid cerebroside sulphate which is then hydrolysed by arylsulphatase A (ASA), whose deficiency results in metachromatic leukodystrophy (M LD ). H owever, this disease phenotype appears also, when functional sap-B is absent. ${ }^{1}$

A neurotrophic function of the precursor prosaposin protein itself has been elucidated, ${ }^{7,8}$ and a role in ganglioside binding and transport has been hypothesized. ${ }^{9}$

Recently, the structure of a saposin-like protein, porcine NK-lysin, representative of a family of sequence related proteins sharing a possible common fold, has been determined, comprising five amphipathic $\alpha$-helices, one at the centre, the others at the two opposite sides, folded into a single globular domain with three disulphide bonds. ${ }^{10}$

In this report we describe a new PSA P mutation causing the production of a nonfunctional sap-B protein in a patient with a late infantile MLD phenotype but with normal ASA activity and increased sulphatide excretion in urine. The mutation, for which the patient is homozygous, causes the loss of the single $\mathrm{N}$-glycosylation site of sap-B and involves a highly conserved residue of sap-B.

\section{Patient}

The male patient (PV) was the second child of first cousins with no history of neurological disorders. At age 2 months an aortic coarctation was diagnosed and repaired. Psychomotor development was delayed. A t about 2 years he presented walking difficulties, loss of fine motor skills and speech regression. Clinical examination at 3 years showed spasticity, axial hypotonia, depressed deep tendon reflexes and mental deterioration. Nerve conduction velocities were markedly slowed. M R I revealed a diffuse hyperintense signal in periventricular and subcortical white matter on $\mathrm{T}_{2}$ weighted images. U Itrastructural analysis of a conjunctival biopsy showed inclusions suggestive of sulphatide deposits in macrophages and endothelial cells. The excretion of sulphatide in urine was elevated. The activity of arylsulphatase A measured with p-nitrocatecholsulphate as substrate was normal in leukocytes and cultured fibroblasts but a reduction in sulphatide degradation was observed in intact growing fibroblasts loaded with $\left[{ }^{14} \mathrm{C}\right.$-stearic acid]-sulphatide. The patient continued to deteriorate and he is still alive at 5 years.

\section{Materials and Methods}

Sulphatide Loading Test

The sulphatide loading test was performed on fibroblasts from patient $P V$, from a late infantile M LD control and from five normal controls as described elsewhere. ${ }^{11}$ Loading of cultured fibroblasts was performed with $\left[{ }^{14} \mathrm{C}\right.$-stearic acid]sulphatide.

\section{First-strand cDNA Synthesis}

Total R NA was extracted from cultured fibroblasts of patient PV and of a normal control using the R Neasy total R NA kit (Q iagen).

$R$ everse transcriptase polymerase chain reaction ( $R T-P C R$ ) was performed in a total volume of $20 \mu \mathrm{l}$ on $100 \mathrm{ng}$ of total RNA using 200 units of SuperScript II R Nase H - Reverse Transcriptase (BRL), 2 pmoles of primer PSAPLR: 5'-CCA A TG CTG TG G TTTCTG CCA A GATG GA A T-3', 10 units of ribonuclease inhibitor ( $B R L)$ in $0.5 \mathrm{~mm}$ dNTPS, $50 \mathrm{~mm}$ Tris- $\mathrm{HCl}(\mathrm{pH} 8.3), 75 \mathrm{~mm} \mathrm{KCl}, 3 \mathrm{~mm} \mathrm{M} \mathrm{gCl}, 10 \mathrm{~mm}$ dithiothreitol (DTT). RNA and primer PSA PLR were heated at $70^{\circ} \mathrm{C}$ for $10 \mathrm{~min}$, then dNTPS, DTT and buffer were added and the resulting solution was incubated at $42^{\circ} \mathrm{C}$ for $2 \mathrm{~min}$. Finally, the ribonuclease inhibitor and the reverse transcriptase were added and the mixture obtained was incubated at $42^{\circ} \mathrm{C}$ for $50 \mathrm{~min}$ followed by a final stage at $70^{\circ} \mathrm{C}$ for $15 \mathrm{~min}$ to inactivate the reverse transcriptase. A fter first-strand cDNA synthesis, 2.2 units of ribonuclease $H$ were added to obtain the degradation of the RNA complementary to the CD NA by incubating the mixture at $37^{\circ} \mathrm{C}$ for $20 \mathrm{~min}$.

The first-strand CD NA was used for the amplification of the portion of the PSA P CDNA encoding sap-B (primers used: PSA PSF: 5'-ATCCCTCTCCTCCTCTACCCTC-3' and PSA PSR : 5'-G CTTCTTAATG G G CTCCA CCAG -3') and of a fragment containing the whole PSA $P$ open reading frame (ORF) (primers PSA PLF: 5'-CCGGCGCTATG TACGCCCTCTTCCTCCTGG-3' and PSAPLR).

\section{Amplification and Direct Sequencing of a PSAP cDNA Segment Containing the sap-B Encoding Region}

To obtain the amplification of a portion of the PSA P CD NA containing the sap-B encoding region, $2 \mu$ l of first-strand CD NA were added, in a total volume of $25 \mu \mathrm{l}$, to $6.25 \mathrm{pmol}$ of primers PSA PSF/PSA PSR in $0.2 \mathrm{~mm}$ dNTPS, $14 \mathrm{~mm}$ Tris- $\mathrm{HCl}$, $56 \mathrm{~mm} \mathrm{KCl}, 1.5 \mathrm{~mm} \mathrm{M} \mathrm{gCl}, 0.8 \mathrm{~mm}$ DTT, with 0.625 units of Taq Polymerase. R eaction parameters were 2 min of denaturation at $94^{\circ} \mathrm{C}$, then $35 \mathrm{cycles}$ of $94^{\circ} \mathrm{C}$ for $1 \mathrm{~min}, 58^{\circ} \mathrm{C}$ for $1 \mathrm{~min}, 72^{\circ} \mathrm{C}$ for $1 \mathrm{~min}$, with a final extension at $72^{\circ} \mathrm{C}$ for $2 \mathrm{~min}$. The expected $400 \mathrm{bp}$ PCR product was sequenced by the Sanger method.

Amplification, Cloning and Automated Sequencing of a PSAP cDNA Segment Containing the Whole PSAP Open Reading Frame

To obtain the amplification of a fragment containing the whole PSA P ORF, $2 \mu \mathrm{l}$ of first-strand CD NA were added, in a 
total volume of $25 \mu \mathrm{l}$, to $7.5 \mathrm{pmol}$ of primers PSA PLF and PSAPLR, in $0.2 \mathrm{~mm}$ dNTPs, $14 \mathrm{~mm}$ Tris- $\mathrm{HCl}, 56 \mathrm{~mm} \mathrm{KCl}$, $1.5 \mathrm{mM} \mathrm{M} \mathrm{gCl} 2,0.8 \mathrm{~mm}$ DTT and 0.875 units of $\mathrm{H}$ igh Fidelity $P C R$ enzyme mix (Boehringer). R eaction parameters were: $94^{\circ} \mathrm{C}$ for $5 \mathrm{~min}$, then addition of enzyme mix, then 10 cycles at $94^{\circ} \mathrm{C}$ for $10 \mathrm{~s}, 63^{\circ} \mathrm{C}$ for $10 \mathrm{~s}, 72^{\circ} \mathrm{C}$ for $1 \mathrm{~min} 30 \mathrm{~s}$, then 25 cycles at $94^{\circ} \mathrm{C}$ for $10 \mathrm{~s}, 63^{\circ} \mathrm{C}$ for $10 \mathrm{~s}, 72^{\circ} \mathrm{C}$ for $1 \mathrm{~min} 30 \mathrm{~s}$ with a delay of $10 \mathrm{~s} / \mathrm{cycle}$, then $10 \mathrm{~min}$ of elongation at $72^{\circ} \mathrm{C}$. R eaction was performed in a $5330 \mathrm{Eppendorf} \mathrm{mastercycler.} \mathrm{The} \mathrm{product}$ obtained was $1632 \mathrm{bp}$ long and comprised the whole OR F of the PSA P gene.

PCR products were cloned in PCR 2.1 (Invitrogen) and transfected in $\mathrm{E}$. coli INV $\alpha \mathrm{F}^{\prime}$ competent cells (I nvitrogen). A PSA $P$ allele from patient PV was identified when screening colonies by PCR using primers PSAPSF/PSA PSR (see above). A positive colony was isolated, plasmid DNA was purified and automated sequence analysis was performed using an $\mathrm{ABI} 373 \mathrm{~A}$ DNA automated sequencer with dye terminator cycle sequencing kit (A pplied B iosystems). Primers PSAPLF, PSAPSF, PSAP2F: 5'-GGAGGTGACCA A GCTGATTGAC-3', PSA PSR, PSA PLR and two vector primers (M 13(-20) and M 13rev) were used for the automated sequencing.

\section{Restriction Analysis on PCR Products from Genomic} DNA

A $n$ amplification from genomic DNA was performed using primers PSA PClaF : 5'-TAGGAACTGGTCAG CAAGCTGC-3' and PSA PClaR: 5'-CCAAGGCCTGGA CAAAGATCGA-3'. The second, carrier of mismatching positions (underlined), produces a Clal restriction site in PCR products obtained from alleles carrying the described mutation. Since it was not possible to obtain the direct amplification of the PSA PClaF/PSA PClaR fragment, a nested-PCR procedure was followed. Primers PSA P4F: 5'-GGGTTCAAGCGATCTGCCTGCC-3' and PSA P4R: 5'-CTCCCAGGCCCAGAACATCCCC-3' were used to get the amplification of a $477 \mathrm{bp}$ fragment containing the PSA PClaF/PSA PClaR tract. 6.25 pmoles of each primer were mixed in a total volume of $25 \mu$ l with $50 \mathrm{ng}$ of genomic DNA in $0.2 \mathrm{~mm}$ dNTPs, $10 \mathrm{~mm}$ Tris- $\mathrm{HCl}(\mathrm{pH} \mathrm{8.3)}, 50 \mathrm{~mm} \mathrm{KCl}$, $1.5 \mathrm{~mm} \mathrm{M} \mathrm{gCl}$. R eaction parameters were $94^{\circ} \mathrm{C}$ for $2 \mathrm{~min}$, then 35 cycles of $94^{\circ} \mathrm{C}$ for $40 \mathrm{~s}, 59^{\circ} \mathrm{C}$ for $40 \mathrm{~s}, 72^{\circ} \mathrm{C}$ for $40 \mathrm{~s}$, followed by 2 min of elongation at $72^{\circ} \mathrm{C} .0 .1 \mu \mathrm{l}$ of this PCR product was used for a subsequent amplification using primers PSA PClaF/ PSA PClaR. A mplification was performed in the same previously described conditions except for the reaction parameters that were $94^{\circ} \mathrm{C}$ for $2 \mathrm{~min}$ followed by 35 cycles of $94^{\circ} \mathrm{C}$ for $30 \mathrm{~s}, 55^{\circ} \mathrm{C}$ for $30 \mathrm{~s}, 72^{\circ} \mathrm{C}$ for $30 \mathrm{~s}$, with a final step of $2 \mathrm{~min}$ at $72^{\circ} \mathrm{C}$. The $200 \mathrm{bp} P C R$ product was Clal-digested for $1 \mathrm{~h}$ at $37^{\circ} \mathrm{C}$. In the presence of the described mutation the $200 \mathrm{bp}$ product is cut into two fragments of $177 \mathrm{bp}$ and $23 \mathrm{bp}$.

\section{Results}

A rylsulphatase A activity of fibroblasts from patient PV measured in vitro was in the normal range, in contrast with his clinical phenotype and with the presence of elevated sulphatides in urine. This fact suggested a possible sap-B deficiency. To investigate this hypothesis, a sulphatide loading test ${ }^{11}$ was per- formed on fibroblasts from patient PV, from a late infantile metachromatic leukodystrophy control, and from five normal controls. A high level of cerebroside sulphate was found compared with normal controls and low levels of galactosyl ceramide and of phosphatidylserine, -inositol, -choline gave additional evidence of a sap-B deficiency (Figure 1 ).

To identify the molecular defect at the DNA level, we performed direct sequencing of the RT-PCR product obtained with primers PSA PSF/PSA PSR, inclusive of the PSA $P$ gene region encoding sap-B. Sequence analysis led to identification of a $\mathrm{C}>\mathrm{A}$ transversion causing an $A$ sn $>$ Lys substitution at position 215 of the PSA P CDNA (Figure 2). This mutation abolishes an $\mathrm{N}$-glycosylation site, the only one in sap-B. M oreover, the substituted $A$ sn residue is highly conserved among human saposins and among saposins B from different species (Figure 3 ). M utation was confirmed on genomic DNA by a nested PCR-RFLP method. Restriction analysis confirmed not only the presence of the $C>A$ transversion causing the described $A$ sn $>$ Lys substitution, but also showed that patient PV was homozygous for this mutation (Figure 4).

RT-PCR performed with primers PSA PLF/PSA PLR produced the expected 1632 bp long product (Figure 5). No aberrant transcript caused by the mutation was identified. Automated sequencing of the cloned PSA LF/PSAPLR fragment excluded the presence of other molecular alterations in the PSA P ORF carrying mutation N215K.

\section{Discussion}

The described PSA P mutation (N215K) is likely to be the cause of a sap-B deficiency responsible of the MLD

\begin{tabular}{lccccc}
\hline & CS & GC & C & PE & PS, PI, PC \\
Patient PV & 64 & 1.0 & 4.0 & 6.3 & 21 \\
LI-MLD control & 87 & 0.0 & 3.4 & 2.1 & 5.8 \\
Normal controls (5) & $16-37$ & $2.1-7.3$ & $4.8-9.0$ & $5.9-13$ & $37-54$ \\
\hline
\end{tabular}

Figure 1 Sulphatide loading test performed on fibroblasts from the patient, from a late infantile M LD control and from five normal controls. L oading of cultured fibroblasts was performed with $\left[{ }^{14} \mathrm{C}\right.$-stearic acid]-sulphatide. Percentages of incorporated lipid radioactivity as found in lipid metabolites in fibroblasts after 3 days are indicated.

CS: cerebroside sulfate; GC: galactosyl ceramide; C: ceramide; PE : phosphatidylethanolamine; PS: phosphatidylserine; PI: phosphatidylinositol; PC: phosphatidylcholine. 
G $\quad A \quad T \quad C$

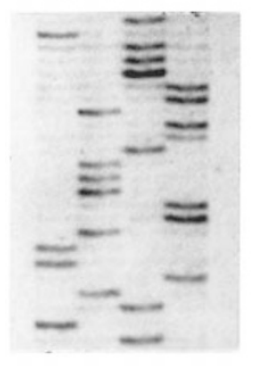

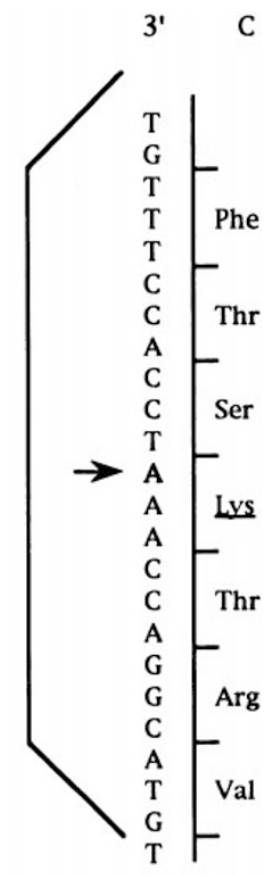

5' N

MUTATED

SEQUENCE
3' C

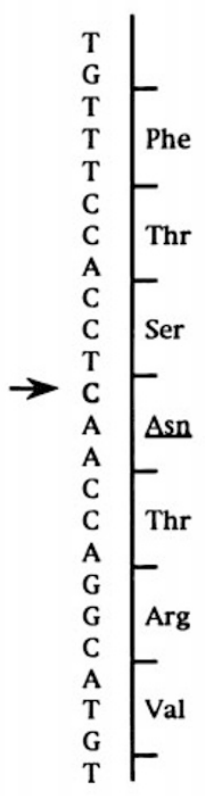

5' $\mathrm{N}$

NORMAL SEQUENCE

Figure 2 Sequence analysis showing the N215K mutation. The sequence gel inset shows the mutated sequence identified in patient $P V$. A rrows indicate the $C>A$ transversion causing the A sn $>$ Lys substitution. The normal sequence is also shown.

phenotype observed in patient PV, who is homozygous for the mutation, as could be suspected from the consanguinity of his parents.

M utation N215K, which involves a residue probably located between the two $\alpha$-helices regions, ${ }^{10}$ is particularly interesting for two reasons: first, the mutation causes the loss of the only $\mathrm{N}$-glycosylation site of sap-B; second, the mutation abolishes a conserved $A$ sn residue ( $A$ sn21 in sap-B).

A bout the loss of the $\mathrm{N}$-glycosylation site, it has been shown that deglycosylated sap-B stimulates the enzymatic hydrolysis of sulphatide by ASA to the same extent as native sap-B, it binds sulphatide just like native sap- $B$, and is as sensitive to proteolytic digestion. ${ }^{12}$ However, deglycosylated and native sap-B refold in a qualitatively different way. ${ }^{12}$ Therefore a defect in folding caused by absence of the $\mathrm{N}$-glycosylation site can be hypothesised.

Concerning the A sn 21 residue, it is conserved among the four human saposins and among saposins B from different species (Figure 3 ). This fact suggests a very

(A)

$\begin{array}{ccc}\text { Sap-A } & \text { TAAGDMLKDNAT EEEILVY } & 12-30 \\ \text { Sap-B } & \text { TDIQTAVRTNSTFVQALVEH } & 12-31 \\ \text { Sap-C } & \text { KEVTKLIDNNKT EKEILDA } & 13-31 \\ \text { Sap-D } & \text { GYLDRNLEKNST KQEILAA } & 13-31 \\ & * *\end{array}$

(B)

\begin{tabular}{|c|c|}
\hline Human & TDIQTAVRTNSTFVQALVEH \\
\hline Mouse & SDVQTAVKTNSSFIQGFVDH \\
\hline Rat & TDIQTAVRTNSSFVQGLVDH \\
\hline Porcine & TDLQNAVRTNSTFVEALVNH \\
\hline Chicken & $\begin{array}{l}\text { TDVQEAVRTNATFVKSLVAH } \\
* * * * * * * \quad * *\end{array}$ \\
\hline
\end{tabular}

Figure 3 Alignment of amino acid sequences of saposins. Portions of saposins aligned are indicated. A mino acids identical in the homologous proteins are marked with *. The conserved asparagine residue in sap- $B$ ( $N$ at position 21 , underlined) is mutated to lysine in the present patient. A) A lignment of human saposins A, B, C, D. B) A lignment of human $^{3}$, mouse $^{20}$, rat $^{21}$, porcine ${ }^{22}$ and chicken ${ }^{23}$ saposins $B$. The conserved asparagine residue involved in mutation N 215K is at position 21 in human sap-B.

\section{$\begin{array}{llll}M & 1 & 2 & 3\end{array}$}

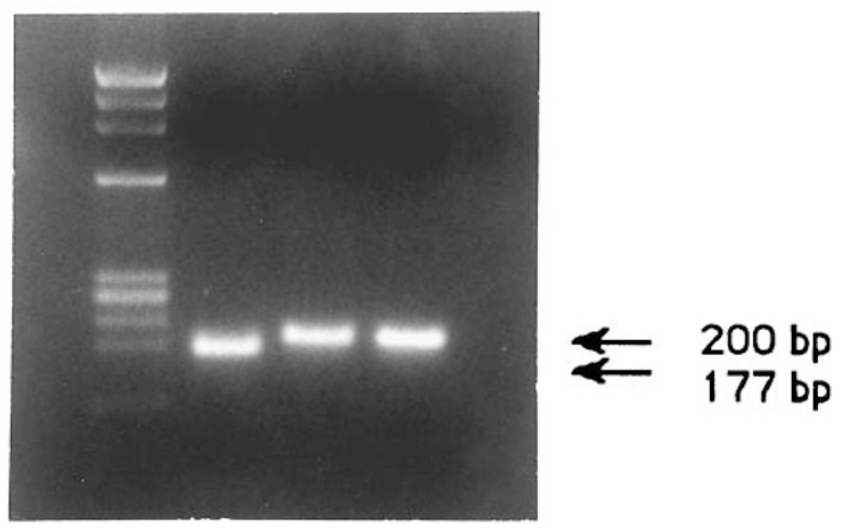

Figure 4 PCR-RFLP identifying the N215K mutation. A mplification from genomic DNA of a fragment of the prosaposin gene encompassing the site of the $\mathrm{N} 215 \mathrm{~K}$ mutation. In the presence of the mutation, the $200 \mathrm{bp}$ product is Claldigested into two fragments of $177 \mathrm{bp}$ and $23 \mathrm{bp}$.

$\mathrm{L}$ ane M: :X 174 DNA Haelll digested; lane 1: patient PV; lanes 2 and 3: normal controls. 


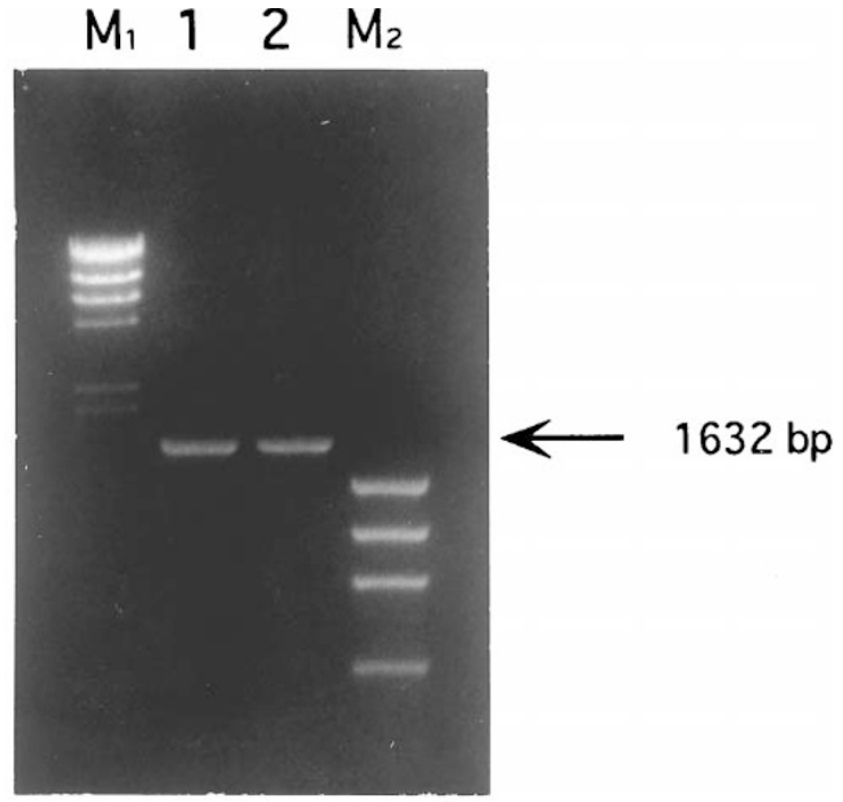

Figure 5 L ong-template PCR: a product comprehensive of the whole ORF. Amplification by RT-PCR of a CDNA fragment containing the whole prosaposin ORF from total RNA.

L ane $\mathrm{M}_{1}$ : $\Lambda$ DNA $\mathrm{H}$ indlII digested; lane 1: patient PV; lane 2: normal control; lane $\mathrm{M}_{2}$ : $\Phi X 174 \mathrm{DNA} \mathrm{H}$ aelll digested.

important role for this residue in the biological activity of the protein.

Probably both these characteristics of the N215K mutation, the consequent loss of the glycosylation site and the involvement of a conserved residue, co-operate in producing a non-functional sap-B protein.

Two other mutations causing the loss of the same $\mathrm{N}$-glycosylation site have been identified, one involving the same A sn21 residue (mutation $\mathrm{N} 215 \mathrm{H}$ ) ${ }^{13}$ the other involving a different residue (Thr23) (mutation T217l).$^{14,15}$

Mutation $\mathrm{N} 215 \mathrm{H}$ has been identified in a patient described as a 4-year-old child with MLD. ${ }^{13}$ M utation T217l has been found in two siblings with a probably milder MLD phenotype than in patient PV, showing first symptoms at 4.5 and 6 years of age respectively, ${ }^{16}$ whilst our patient showed walking difficulties at 2 years and mental retardation at 3 . Interestingly, the Thr23 residue is conserved in human, porcine and chicken sap- $B$, but is not conserved in mouse or rat sap-B, whilst the $A$ sn 21 residue is conserved in the saposins $B$ from all these five species (Figure 3). A severe form of the disease can be expected in consequence of a mutation involving such a highly conserved residue.

No aberrant transcript due to the N215K mutation has been identified. Therefore the regularly transcribed
mR NA must encode a mutated prosaposin protein. We can speculate that point mutation N 215K cannot affect sorting, nor the subsequent processing of the protein, thus leading to the production of normal sap-A , sap-C, sap-D and mutated sap-B. In the case of mutation $\mathrm{N} 215 \mathrm{H}$, which involves the same residue of mutation $\mathrm{N} 215 \mathrm{~K}$, the four saposins were detected by immunochemical methods. ${ }^{13}$ Since no anti-saposin antibodies were available for our study, we could not confirm a positive immunoreactivity for the products of the N 215K mutated prosaposin but, with the results of the $\mathrm{N} 215 \mathrm{H}$ mutated case, positive immunoreactivity also of sap-B with N215K mutation is very likely.

We can exclude the concept that N215K mutated prosaposin protein can be defective as a neurotrophic factor: ${ }^{7,8}$ in fact, the portion of the protein involved in this role lies in the sap-C region. To date five other M LD -causing sap-B mutations have been identified in the PSAP gene. ${ }^{13-15,17-19}$ A II patients carrying these mutations are homozygotes for their particular molecular defect. The low number of MLD-causing PSA P mutations identified to date could also be ascribed to a possible underestimation of the disease at the diagnostic level.

\section{Acknowledgements}

This work was supported by I talian Telethon grant C.20. Cell lines were obtained from the collection ' $C$ ell lines and DNA bank from patients affected by genetic disease' supported by I talian Telethon.

\section{References}

1 Sandhoff K, Harzer K, Fürst W: Sphingolipid activator proteins. In: Scriver CR, B eaudet A L, Sly WS, Valle D (eds). The Metabolic and Molecular Bases of Inherited Disease, 7th edn. McGraw-Hill: New York, 1995, pp 2427-2441.

2 O'B rien J S, K retz KA, Dewji N, Wenger DA, Esch $F$, Fluharty $A L$ : Coding of two sphingolipid activator proteins (SA P-1 and SA P-2) by same genetic locus. Science 1988; 241: 1098-1101.

3 Nakano T, Sandhoff K, Stumper J, Christomanou H, Suzuki K: Structure of full-length CDNA coding for sulfatide activator, a co-beta-glucosidase and two other homologous proteins: two alternate forms of the sulfatide activator. J Biochem 1989; 105: 152-154.

4 R orman E G, Scheinker V, G rabowski G A : Structure and evolution of the human prosaposin chromosomal gene. G enomics 1992; 13: 312-318. 
5 A zuma N, O'B rien J S, M oser HW, K ishimoto Y: Stimulation of acid ceramidase activity by saposin D. Arch Biochem Biophys 1994; 311: 354-357.

6 Klein A, Henseler M, Klein C, Suzuki K, Harzer K, Sandhoff K: Sphingolipid activator protein D (sap-D) stimulates the lysosomal degradation of ceramide in vivo. Biochem Biophys Res Commun 1994; 200: 1440-1448.

7 O 'Brien J S, Carson G S, Seo H-C, H iraiwa M, K ishimoto $Y$ : Identification of prosaposin as a neurotrophic factor. Proc Natl A cadi Sci USA 1994; 91: 9593-9596.

8 O'Brien J S, Carson G S, Seo H -C et al: I dentification of the neurotrophic factor sequence of prosaposin. FASEB J 1995; 9: 681-685.

9 Hiraiwa M, Soeda S, K ishimoto $Y, O^{\prime}$ Brien J S: Binding and transport of gangliosides by prosaposin. Proc $\mathrm{N}$ atl A cad Sci USA 1992; 89: 11254-11258.

10 Liepinsh $E$, A ndersson $M, R$ uysschaert J $M, O$ tting $G$ : Saposin fold revealed by the NMR structure of NK-lysin. $\mathrm{N}$ at Struct Biol 1997; 4: 793-795.

11 Kudoh T, Wenger DA: Diagnosis of metachromatic leukodystrophy, K rabbe disease and Farber disease after uptake of fatty acid-labeled cerebroside sulfate into cultured skin fibroblasts. J Clin Invest 1982; 70: 89-97.

12 H iraiwa M, Soeda S, Martin BM et al: The effect of carbohydrate removal on stability and activity of saposin B. A rch Biochem Biophys 1993; 303: 326-331.

13 Wrobe $D$, Henseler $M$, Chabas A, Sandhoff K: A $n$ unglycosylated, stable but inactive mutant $(\mathrm{N} 215 \mathrm{H})$ of the sphingolipid activator protein $B$ in a novel case of metachromatic leukodystrophy.. XI European Study Group on Lysosomal Diseases Workshop 1997, p. 60 (abstract)

$14 \mathrm{~K}$ retz KA, Carson GS, M orimoto S, K ishimoto $Y$, Fluharty $A L, O$ 'B rien JS: Characterization of a mutation in a family with saposin B deficiency: a glycosylation site defect. Proc Natl A cad Sci USA 1990; 87: 2541-2544.
15 R afi $M A, Z$ hang $X-L, D$ eG ala $G$, Wenger $D A$ : D etection of a point mutation in sphingolipid activator protein-1 mRNA in patients with a variant form of metachromatic leukodystrophy. Biochem Biophys Res Commun 1990; 166: 1017-1023.

16 Shapiro LJ, A leck KA, K aback M M et al: $M$ etachromatic leukodystrophy without arylsulfatase A deficiency. Pediatr Res 1979; 13: 1179-1181.

17 Zhang $X-L$, R afi M A, D eG ala G, Wenger DA : Insertion in the mRNA of a metachromatic leukodystrophy patient with sphingolipid activator protein-1 deficiency. P roc $\mathrm{N}$ at A cad Sci USA 1990; 87: 1426-1430.

$18 \mathrm{H}$ oltschmidt H, Sandhoff K, K won HY, H arzer K, Nakano T, Suzuki K : Sulfatide activator protein. J Biol Chem 1991; 266: 7556-7560.

19 Henseler M, K lein A, R eber M, Vanier MT, Landrieu P, Sandhoff $K$ : A nalysis of a splice-site mutation in the sapprecursor gene of a patient with metachromatic leukodystrophy. A m J H um G enet 1996; 58: 65-74.

20 Tsuda M, Sakiyama T, E ndo H, K itagawa T: The primary structure of mouse prosaposin. Biochem Biophys Res Commun 1992; 184: 1266-1272.

21 Collard M W, Sylvester SR, Tsuruta JK, G riswold MD: Biosynthesis and molecular cloning of sulfated glycoprotein 1 secreted by rat Sertoli cells: sequence similarity with the 70-kilodalton precursor to sulfatide/GM 1 activator. Biochemistry 1988; 27: 4557-4564.

22 Stevens RL, Faull KF, Conklin KA, Green BN, Fluharty $A L$ : Porcine cerebroside sulfate activator: further structural characterization and disulfide identification. Biochemistry 1993; 32: 4051-4059.

23 A zuma N, Seo H-C, Lie $\mathrm{O}$ et al: Cloning, expression and map assignment of chicken prosaposin. Biochem J 1998; 330: 321-327. 